extended. But an appeal to the British Colonies in Africa has met with a response which enables the Department to continue.

This news will be welcomed not only in Great Britain and in the British Colonies in Africa, but by every one interested in the study of African languages and cultures. The School has a great tradition and has on its teachers' roll such famous names as that of Professor Alice Werner, and many are those who through attending its African courses have become more efficient in the service of Africa. It is to be hoped that Governments and Missions will in the future even more than in the past send their candidates to the School so that they may be enabled to prepare themselves for their work among Africans.

\title{
Vernacular Periodicals Nos. 24 and 25. Lukwilu bweto (Notre foi) et Longete (Enseignez).
}

LE Vicariat apostolique du Kwango (Congo Belge) édite depuis 1933 en Kikongo un journal mensuel, le Lukwilu bweto, dont le but est d'entretenir et de compléter auprès des chrétiens et catéchumènes de la circonscription, les connaissances religieuses et profanes. Étant donné les objectifs qu'il désire atteindre, le sommaire de chaque numéro se présente comme suit: une communication de l'évêque à ses fidèles, le commentaire de l'intention mensuelle de l'apostolat et de la prière, un article d'instruction religieuse, une fable ou historiette dont la conclusion morale est brièvement commentée, un article de vulgarisation scientifique, des nouvelles de l'église à travers le monde, de la Belgique et surtout des différents postes du Kwango, un concours avec prix en guise de propagande. Il n'est pas exagéré d'affirmer que les 6000 abonnés ne représentent que la moitié des lecteurs du journal: on se le passe en seconde lecture dans les villages et les illettrés eux-mêmes se le font lire. Le numéro ordinaire présente huit pages de texte, les numéros de Noël, Pâques et Assomption en comptent seize.

Dès la seconde année en 1934 un supplément sous forme de page de catéchiste y fut joint. Baptisé du nom de Longete, celui-ci se transformait quelques mois plus tard en un petit journal de huit pages. Le but à poursuivre est d'aider les catéchistes-instituteurs, répandus à travers tout le territoire du Kwango, à bien remplir les devoirs de leur charge. A cet effet, il donne dans le domaine religieux des directives et des conseils, et établit au point de vue de l'enseignement un contact contenu entre le missionaire-inspecteur et chacune des écoles rurales. (D'après A. CHÉville, missionnaire au Kwango, dans la 'Revue Missionnaire').

\section{The Nigerian Field Society}

THrs Society was started in 1930. It has at present a membership of about 650, most of whom live in Nigeria, but some also in the Gold Coast, Sierra Leone, and The Gambia. 'The primary object of the Society is to encourage 
interest in, and knowledge of, the wild life of the country (faunal and floral), the customs, history, arts and crafts of its peoples, and sports of all kinds. It publishes a quarterly journal, The Nigerian Field, and it encourages interest in native arts and crafts and in history by awarding prizes for school essays; another object is the institution of a National Museum of Natural History, Ethnography, and History.

The membership fees are (a) $£ \mathrm{I}$ for Fellows, $(b)$ ros. for Members, and (c) ss. for Associates. The latter grade is open to Africans only, but Africans are also eligible for $(a)$ and $(b)$.

The Journal is of a high standard, with excellent illustrations and so varied in its contents that the surprisingly large membership of the Society can be well understood. Some of the subjects dealt with in the July and October numbers, 1938, are: 'The distribution of Negro Sculpture in Southern Nigeria', 'A visit to Old Oyo' (the ancient Yoruba capital, also called Katunga, which was destroyed in I837 by the Fulani), "An Ibo Autobiography' (by Eke Kalu, who was born about I875), native stories, serial articles on antelopes and other animals and on plant life, among them one on some West African shrubs, trees, and vines now growing in the United States. The Nigerian Field is also of importance to anthropologists; it provides information not found elsewhere.

\section{The Study of African Languages.}

THE article published under this title in the January number of Africa has been received with great interest. In order to stimulate further investigations the Editor would be grateful if readers would criticize or supplement the statements made in that article, for it is natural that in very many cases only individuals on the spot can give a true picture of the linguistic situation and needs in a district, or they may be able to supply information which is not known outside a narrow circle.

One piece of valuable information of this kind has been contributed by the Rev. A. Prost, Procure des Pères Blancs, Paris, who says that a Dictionnaire Moré (Mossi)-Français and Français-Moré, as well as a very complete Grammar of the same language, was prepared by the Rev. P. Alexandre and published in 1935 by the Maison Carrée in Algiers.

Father Prost has himself compiled a Dictionary of 275 pages of Bisa, the language of the Boussanse, a Mandingo tribe in Mossi country, closely allied to Samo and to Busa. This has not been printed, but typed and duplicated. He is also preparing a Grammar of this language. 